\title{
Navigating Risk When Entering and Participating in a Business Ecosystem
}

\author{
Derek Smith
}

\author{
"The biggest dangers to a company are the ones you don't see") \\ coming. Understanding these threats - and anticipating \\ opportunities - requires strong peripheral vision.
}

George S. Day \& Paul J.H. Shoemaker

(tinyurl.com/c7x75jt)

\begin{abstract}
Entrepreneurs typically have limited resources during the start-up phase of a business. Business ecosystems are a strategy for entrepreneurs to access and exchange many different aspects of value, resources, and benefits. However, there may be business risks for entering a particular type of ecosystem, and further risks may be encountered after entering and participating in a business ecosystem. These risks are significant and can inhibit a startup's growth. In this article, the literature on business ecosystems is reviewed as it relates to risk to discover insights of relevance to entrepreneurs, top management teams, and business-ecosystem operators. First, the published research is organized into two streams: i) risks relating to categories of business ecosystems, and ii) risks relating to participating in business ecosystems. Then, the problem is abstracted to develop a potential strategy for managing these risks, which features a pre-entry inspection followed by realtime resource management. Finally, five recommendations are offered for entrepreneurs seeking to enter and participate in business ecosystems.
\end{abstract}

\section{Introduction}

Entrepreneurs must overcome significant challenges when starting up a company. They often face limited funding, a lack of resources, and a broad range of technical challenges. Creating foundational technology is time consuming, and it can be wasteful. Business ecosystems can help entrepreneurs, but a proper approach is key to providing value to the business. If the approach is mishandled, it can create additional challenges for the entrepreneur.

Entering into a business ecosystem is a powerful way to address these start-up issues by providing access to resources, foundational technology, customers, and alliances. Peltoneimi and Vuori (2004; tinyurl.com/ cwtd63x) define a business ecosystem as: “... a dynamic structure which consists of an interconnected population of organizations. These organizations can be small firms, large corporations, universities, research centers, public sector organizations and other parties, which influence the system ... to include a population of organizations. Business ecosystem develops through self-organization, emergence and co-evolution which help it to acquire adaptability." A business ecosystem includes both cooperation and competition: it is an environment characterized by both opportunity and risk.

An entrepreneur must be able to navigate risk before and after entry into a business ecosystem; otherwise, these risks could create a multitude of more serious challenges at a time when the startup is vulnerable. "For many companies, however, the attempt at ecosystem innovation has been a costly failure. This is because, along with new opportunities, innovation ecosystems also present a new set of risks - new dependencies that can brutally derail a firm's best efforts." Adner (2006; tinyurl.com/bpj4syf). 


\section{Navigating Risk When Entering and Participating in a Business Ecosystem}

\section{Derek Smith}

Entrepreneurs need to identify and understand the categories of business ecosystems, the stage of ecosystem evolution, and the associated participation risks. Early identification of the main actor - or keystone (Iansiti and Levien, 2004; tinyurl.com/bkg9vfl) - in the business ecosystem is also important. They also need to anticipate what risks they will be exposed to at two different points in time: before and after entering a business ecosystem. However, business ecosystems are a relatively new area of research, and therefore, the research into their specific risks is limited and cannot be sufficiently generalized to help entrepreneurs make decisions. Here, we ask: "What are the different types of risk in a business ecosystem, and how should an entrepreneur identify these risks"?

This article makes four contributions. First, it argues that entrepreneurs should consider business ecosystems as a viable option for startups. This argument complements the conventional perspective of business ecosystems as a means to share value and resources. Second, it identifies twelve published research articles on business ecosystem risks and summarizes their contents. Third, it distinguishes between business ecosystem category risks and participation risks. Fourth, it provides five recommendations to entrepreneurs seeking to effectively enter and participate in business ecosystems.

The body of this article is organized in three sections. The first section provides an overview of the research method, includes a review of the literature on business ecosystems as it relates to risk. The second section provides an abstraction of a business ecosystem into a dynamic constantly changing environment characterized by both risk and value to identify a broad solution to the problem. The third section provides recommendations for entrepreneurs. A final section concludes the article.

\section{Literature Review}

The literature review of business ecosystems began with a search in the Business Source Complete (tinyurl.com/ 22teqry) database on the keyword "business ecosystem". When restricted to the author-supplied-keyword field and full-text scholarly journals, the query identified 33 individual articles, with the earliest publication in 2001. A review of the abstract and introduction of the 33 articles identified a subset of 8 articles about business ecosystem categories and risks. The references of these articles were examined and 4 additional articles were added to this set for a total of 12 articles. Articles unrelated to categories and risks of business ecosystems were set aside.

The 12 articles were published in 10 different journals and conference proceedings. Two journals - the Harvard Business Review and the Strategic Management Journalpublished two articles each from the set. The journals vary widely in disciplinary focus, including management, business, strategy, leadership and marketing.

The 12 articles were organized into two different streams: i) risks associated with business-ecosystem categories and ii) risks associated with participating in business ecosystems. Organizing the literature in this way revealed insight into business-ecosystem risks. Table 1 and Table 2 summarize the field settings, research designs, and unique contributions of the articles in each literature stream.

\section{Risks associated with a category or type of business ecosystem}

There are three articles summarized in Table 1 that relate to business-ecosystem categories. Purdy and colleagues (2012; tinyurl.com/bs9n5h2) identify three categories of business ecosystem: i) harbor and fleet, ii) demand forum, and iii) multivalent sourcing. In the harbor and fleet (platform) ecosystems, the harbor firm provides underlying or foundational resources and the fleet of companies gain access to the harbor and resources. Example harbors include Amazon (amazon.com) and Athenahealth (athenahealth.com), which offers cloudbased administrative services to medical practitioners. A demand forum ecosystem extends markets for suppliers and provides wider choices to customers. Examples include Yipit (yipit.com), a company that brings together local deals from many different Internet sources, and One Block Off the Grid (lbog.org), a community to attract a critical mass of buyers to negotiate a mass discount for solar panels. The multivalent sourcing category relates to acquiring materials, talent, and capital for production by creating economies of scale through the Internet. An example is Napkin Labs (napkinlabs.com), a crowdsourcing consulting company. Risks associated with harbor and fleet ecosystems relate to losing intellectual property rights. Risks with demand forum and multivalent sourcing ecosystems relate to businessmodel replication in local markets. Additional risks include complexity of relationship management and surrendering control. 


\section{Navigating Risk When Entering and Participating in a Business Ecosystem}

\section{Derek Smith}

Table 1. Summary of literature on risks associated with business-ecosystem categories

\begin{tabular}{|c|c|c|c|c|}
\hline $\begin{array}{l}\text { Author } \\
\text { (Year) }\end{array}$ & $\begin{array}{l}\text { Journal or } \\
\text { Conference }\end{array}$ & Field Setting(s) & Research Design & Contribution \\
\hline $\begin{array}{l}\text { Koenig (2012) } \\
\text { tinyurl.com/cck69qa }\end{array}$ & M@n@gement & n.a. & $\begin{array}{l}\text { Review and analysis of } \\
\text { business ecosystem } \\
\text { definitions and designs by } \\
\text { different scholars }\end{array}$ & $\begin{array}{l}\text { Contrasts and compares different } \\
\text { definitions by Moore. Proposes a } \\
\text { typology of four different categories of } \\
\text { business ecosystems, associated } \\
\text { control or resources, and degree of } \\
\text { participation among the members of } \\
\text { each ecosystem category: supply } \\
\text { systems, platform, communities of } \\
\text { destiny, and expanding communities. }\end{array}$ \\
\hline $\begin{array}{l}\text { Moore (1993) } \\
\text { tinyurl.com/bnbulcj }\end{array}$ & $\begin{array}{l}\text { Harvard Business } \\
\text { Review }\end{array}$ & $\begin{array}{l}\text { Cross industry, personal } \\
\text { computer hardware, } \\
\text { operating systems, } \\
\text { software, automobile } \\
\text { industry, retail industry, } \\
\text { and pharmaceuticals }\end{array}$ & $\begin{array}{l}\text { Proposition for the four } \\
\text { evolutionary stages of a } \\
\text { business ecosystem }\end{array}$ & $\begin{array}{l}\text { Identifies the four evolutionary stages } \\
\text { of a business ecosystem: birth, } \\
\text { expansion, leadership, and self- } \\
\text { renewal. For each stage, identifies the } \\
\text { cooperative and competitive challenges } \\
\text { in the ecosystem. }\end{array}$ \\
\hline $\begin{array}{l}\text { Purdy et al. (2012) } \\
\text { tinyurl.com/bs9n5h22 }\end{array}$ & $\begin{array}{l}\text { Strategy \& } \\
\text { Leadership }\end{array}$ & n.a. & $\begin{array}{l}\text { Proposition of three designs } \\
\text { or categories of business } \\
\text { ecosystems by examples of } \\
\text { companies to include: } \\
\text { Amazon, Athenahealth, } \\
\text { Yipit, 1BOG, Polyvore, SOI, } \\
\text { Napkin Labs, and GrowVC }\end{array}$ & $\begin{array}{l}\text { Proposes a typology of three different } \\
\text { categories of business ecosystems to } \\
\text { include harbor and fleet (platform), } \\
\text { demand forum (supply systems), and } \\
\text { multivalent sourcing (expanding } \\
\text { communities). }\end{array}$ \\
\hline
\end{tabular}

Koenig (2012; tinyurl.com/cck69qa) identifies four categories of business ecosystem: i) platforms, ii) supply systems, iii) expanding communities, and iv) communities of destiny. Platforms have reciprocal interdependence and centralized control of key resources by the firm providing the key resources. Supply systems have pooled interdependence and centralized control of key resources. An example of a supply system is Nike (nike.com), which controls a system of resources. Expanding communities have reciprocal interdependence and decentralized control of key resources. This type of ecosystem is usually a knowledge-exchange community, such as an open source community. Finally, communities of destiny have pooled interdependence and decentralized control of key resources. The Sematech consortium (sematech.org) in the semi-conductor industry is an example of a community of destiny. Risks associated with each of these categories of business ecosystem vary, but are directly related to control (centralized or decentralized) and interdependence (pooled or reciprocal).

The six categories of business ecosystem identified from the literature are shown in Table 3 . The main characteristics, attributes, activities, and examples are summarized for each category.
In summary, the risks associated with the category of business ecosystem include:

1. General risks:

- complexity of relationship management (between actors and the keystone)

- control (centralized or decentralized)

- co-opetition (simultaneous cooperation and competition)

2. Platform risks:

- potential loss of intellectual property rights

- centralized control of key resources

- actor/keystone reciprocal interdependence

3. Expanding Communities risks:

- actor/keystone reciprocal interdependence

4. Communities of Destiny risks:

- actor/keystone pooled interdependence

5. Multivalent and Demand Forum risks:

- replication of the company's business model by competitors 


\section{Navigating Risk When Entering and Participating in a Business Ecosystem}

\section{Derek Smith}

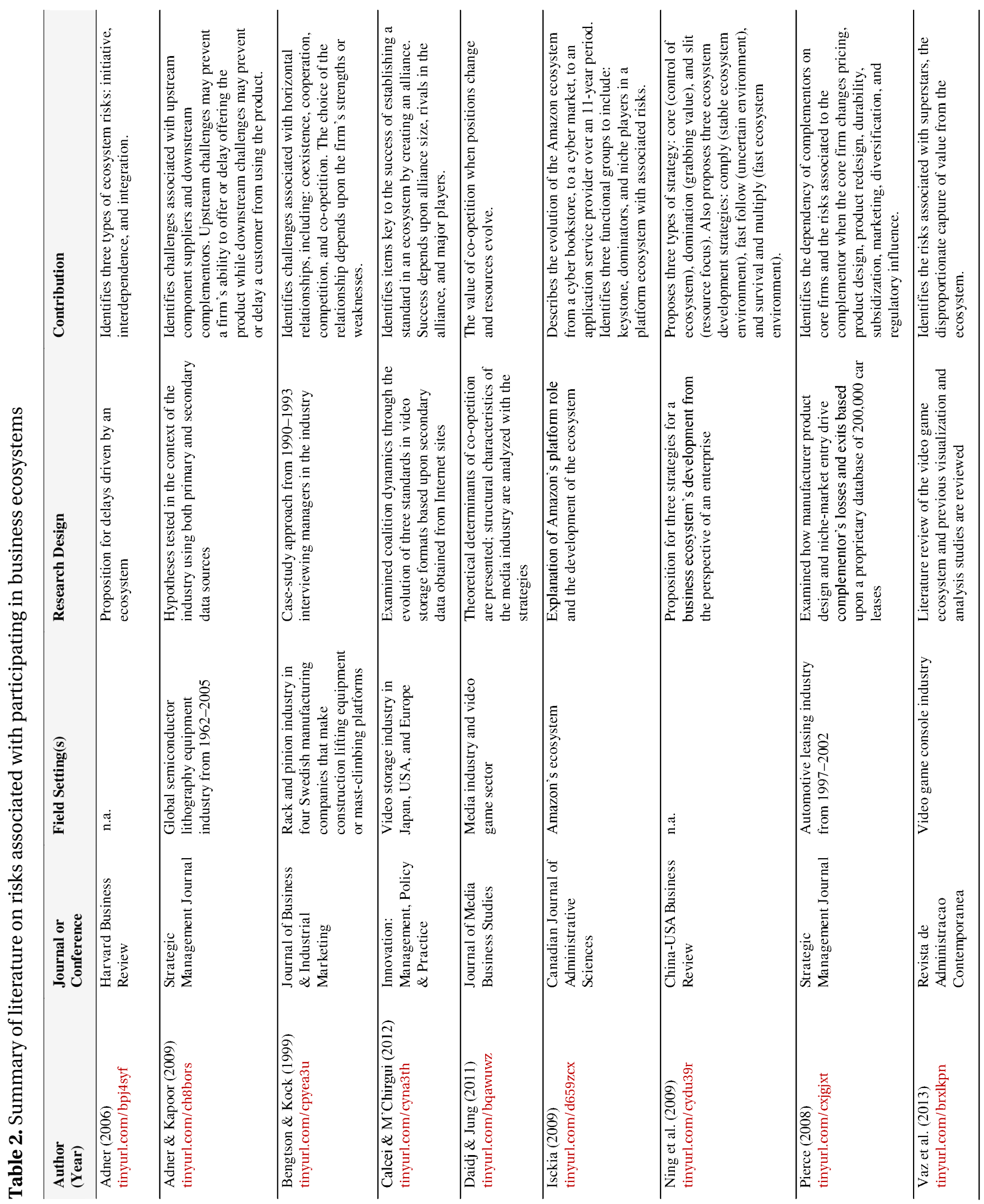




\section{Navigating Risk When Entering and Participating in a Business Ecosystem}

\section{Derek Smith}

Table 3. Prominent attributes and examples of business-ecosystem categories*

\begin{tabular}{|c|c|c|c|c|c|}
\hline Category & Characteristics & Main Actor & Access & Activities & Examples \\
\hline $\begin{array}{l}\text { Platforms / } \\
\text { Harbor and Fleet }\end{array}$ & $\begin{array}{l}\text { A main actor that operates a } \\
\text { platform and infrastructure. } \\
\text { Shares a key asset, or resource, } \\
\text { or services to other smaller } \\
\text { actors in the business } \\
\text { ecosystem. The main actor } \\
\text { specifies the rules that must be } \\
\text { followed for use of the platform. }\end{array}$ & Yes & General & $\begin{array}{l}\text { Main actor shares for } \\
\text { mutual economic } \\
\text { benefits. Other actors use } \\
\text { the key resource or } \\
\text { services in developing } \\
\text { their own products or } \\
\text { services. }\end{array}$ & $\begin{array}{l}\text { Amazon, Athenahealth, } \\
\text { IBM 360, Video game } \\
\text { consoles, Apple's iPod }\end{array}$ \\
\hline Demand Forum & $\begin{array}{l}\text { A main actor that aggregates } \\
\text { other actors together in the } \\
\text { business ecosystem. Brings } \\
\text { together buyers and sellers. }\end{array}$ & Yes & General & $\begin{array}{l}\text { Main actor aggregates } \\
\text { buyers and sellers for } \\
\text { increased range of goods } \\
\text { and services and } \\
\text { discounts prices. }\end{array}$ & Yipit, 1BOG, Polyvore \\
\hline Multivalent & $\begin{array}{l}\text { A main actor that supplies } \\
\text { resources such as talent, } \\
\text { innovation, funding, and raw } \\
\text { materials for production. }\end{array}$ & Yes & General & $\begin{array}{l}\text { Main actor provides } \\
\text { information and } \\
\text { resources to other actors } \\
\text { in the form of } \\
\text { crowdsourcing. }\end{array}$ & $\begin{array}{l}\text { Prime Advantage, } \\
\text { Napkin Labs, GrowVC, } \\
\text { InnoCentive }\end{array}$ \\
\hline Supply Systems & $\begin{array}{l}\text { A main actor is lacking in certain } \\
\text { key resources. The key resources } \\
\text { are obtained from a select group } \\
\text { of other actors that provide the } \\
\text { key resources to the main actor. } \\
\text { The main actor controls the } \\
\text { other actors. }\end{array}$ & Yes & Privileged & $\begin{array}{l}\text { Other actors supplying } \\
\text { key resources or services } \\
\text { to a main actor in product } \\
\text { development. }\end{array}$ & Nike \\
\hline $\begin{array}{l}\text { Expanding } \\
\text { Communities }\end{array}$ & $\begin{array}{l}\text { A large number of actors that are } \\
\text { grouped around a central non- } \\
\text { proprietary resource for the } \\
\text { benefit of all actors. }\end{array}$ & No & Membership & $\begin{array}{l}\text { Software development of } \\
\text { the non-proprietary } \\
\text { resource. }\end{array}$ & $\begin{array}{l}\text { Knowledge-intensive } \\
\text { communities, open } \\
\text { source communities, } \\
\text { Nikonians }\end{array}$ \\
\hline $\begin{array}{l}\text { Communities of } \\
\text { Destiny }\end{array}$ & $\begin{array}{l}\text { No key assets. Actors organize } \\
\text { through solidarity around a } \\
\text { central issue to their existence in } \\
\text { an industry. }\end{array}$ & No & Membership & $\begin{array}{l}\text { All actors cooperate to } \\
\text { resolve central issues to } \\
\text { their mutual benefit in } \\
\text { industry. }\end{array}$ & Sematech \\
\hline
\end{tabular}

*Based on descriptions in Koenig (2012; tinyurl.com/cck69qa) and Purdy et al. (2012; tinyurl.com/bs9n5h2)

Moore (1993; tinyurl.com/cygzy60) identifies risks relating to the four evolutionary stages of a business ecosystem: birth, expansion, leadership, and self-renewal. These risks are contrasted between the cooperative and competitive aspects for each stage and include:

\section{Working with customers or protecting ideas at birth}

2. Bringing new ideas to market, working collaboratively, or defeating similar ideas during expansion

3. Providing a compelling vision for the future or maintaining status quo during the leadership phase
4. Working with innovators or maintaining high barriers during the self-renewal phase

\section{Risks associated with participating in the business} ecosystem

As summarized in Table 2, there are nine articles that relate to after-entry risks associated with participating in business ecosystems. Adner (2006; tinyurl.com/bpj4syf) identifies delay-risks relating to the type of business activity, interdependence (joint probability of succeeding on time) and integration (intermediaries between the company and the customer). These risks relate to delays in development or time to market and participa- 


\section{Navigating Risk When Entering and Participating in a Business Ecosystem}

\section{Derek Smith}

tion with other actors. Adner and Kapoor (2009; tinyurl .com/ch8bors) identify further delay-risks based upon the company's location in the ecosystem and its upstream relationships (component suppliers) and downstream relationships (complementors). The risk of delay may be high or low depending upon the magnitude of the risk. Bengtsson and Kock (1999; tinyurl.com/cpyea3u) identify risks with horizontal relationships as they relate to co-existence, cooperation, competition, and co-opetition, essentially, the impact of weak relationships and the change in the relationship. Calcei and M'Chirgui (2012; tinyurl.com/cyna3th) identify the risk associated with technology-standard wars and the risk of building the best alliance with competitors and all of the key actors to ensure success. Daidj and Jung (2011; tinyurl.com/ bqawuwz) identify the risks associated with rapid change and convergence in an industry and the need to reorganize with the best alliances as the company transitions into co-opetition relationships. Isckia (2009; tinyurl.com/ c659zcx) identifies the risks encountered when participating with a keystone that operates at both ends of the supply chain. There is risk that a transformation may change the nature of the relationships. There is also risk that a keystone may attract a new actor that presents a threat to the company. Pierce (2008; tinyurl.com/cxjgjxt) identifies risks relating to the participation between a core actor and niche player. Changes in a core actor's products and service may force a niche player to exit the business ecosystem. Vaz and colleagues (2012; tinyurl.com/brxlkpn) identify risks when one actor creates a "superstar" product or service that takes a disproportional amount of value in the business ecosystem. Finally, Ning and colleagues (2009; tinyurl.com/cydu39r) identify risks associated with participating with a dominator that takes full advantage of resources and value.

In summary, the risks associated with participating in a business ecosystem relates to four key areas:

\section{General risks:}

- horizontal (co-existence, cooperation, competition, and co-opetition)

- nature of the relationships

- establish the best alliances

- relationship between core actors and niche players

- changes in core actors' products and services forcing a niche player exit

- one actor creates a superstar product or service causing an imbalance in the business ecosystem

- delays relating to the initiative, interdependence, and integration

- dominating actors causing an imbalance in the business ecosystem
2. Keystone risks:

- operating at both ends of the supply chain

- threats from new actors attracted by the keystone

3. Risks from location in the value chain:

- upstream relationships (component suppliers)

- downstream relationships (complementors)

\section{Standards risks:}

- wars

- establishing the best coalition with actors

- rapid change

- convergence in an industry

\section{Abstracting the Problem}

An abstraction removes dependencies on the original context, in this case a business ecosystem that might limit or narrow the ability to identify potential solutions to the problem. Business ecosystems are a dynamic and constantly changing environment with associated risks that can make it difficult to grow value or, conversely, that can destroy value. This type of environment can be abstracted into a general framework of a dynamic, constantly changing environment with significant risks and potential value.

As an example of how this abstraction relates to other dynamic and constantly changing environments with risks, consider aviation. Pilots do not simply get into the cockpit and start flying the aircraft. Rather, a pilot knows in advance what type or category of aircraft they will be flying, and they will conduct a systematic preflight inspection of the aircraft. The type of inspection varies depending on the type of aircraft and the typical risks associated with it. Next, they use a checklist and conduct a systematic pre-flight inspection to ensure the aircraft is ready for flight, and this procedure varies based upon the category and type of aircraft. Once in the air, the pilot manages the cockpit resources, which includes threat management during all stages of the flight, and they proactively take any necessary corrective actions to deal with the risks. Despite significant risks associated with aviation, pilots are able to maximize the likelihood of a successful flight through their knowledge of these risks, the pre-flight inspections they make, and their real-time actions during the flight to monitor and manage potential threats.

Pilots receive training before earning their pilot's license, and they are very familiar with the category of aircraft they fly. Although entrepreneurs do not need an "ecosystem license" to participate in a business ecosys- 


\section{Navigating Risk When Entering and Participating in a Business Ecosystem}

\section{Derek Smith}

tem, the abstraction described here illustrates parallel preparations that entrepreneurs should take before entering a business ecosystem and actions they should take while they interact within it. Entrepreneurs should identify the category of business ecosystems and associated risks prior to entering a business ecosystem. As shown in Figure 1, entrepreneurs need to conduct preentry inspections from different viewpoints to ensure risks are known and manageable prior to entry. Table 4 is a business ecosystem pre-entry checklist, which identifies risks with six categories of business ecosystem. This checklist is a synthesis of the potential risks across the six categories of business ecosystems. The pre-entry inspection should also identify the evolutionary stage of the ecosystem and associated risks. For example, upon conducting a pre-entry inspection the entrepreneur may discover a potential risk for loss of intellectual property rights for a platform business ecosystem they are looking to enter. One option to mitigate this potential risk is protecting the company's intellectual property before entering the business ecosystem.

Upon entering the business ecosystem, entrepreneurs need to constantly monitor and manage threats through real-time resource management when particip-

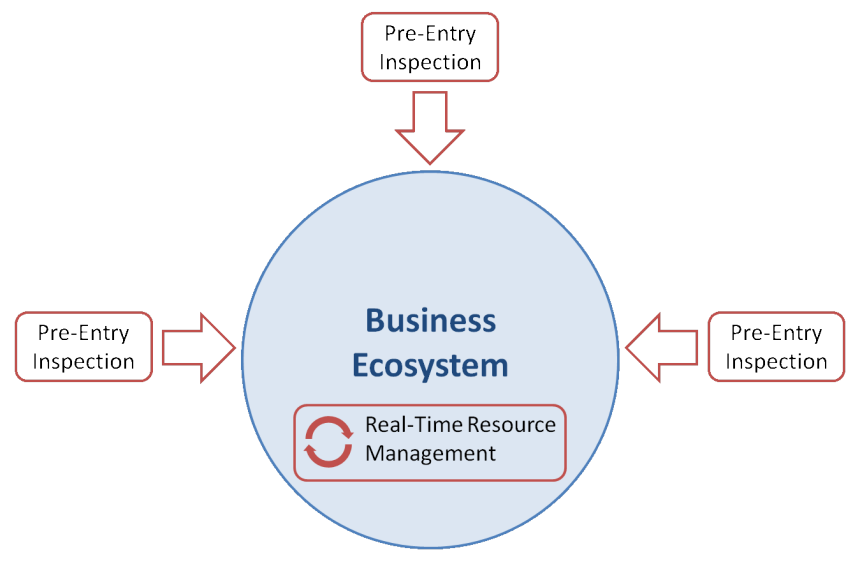

Figure 1. Risk management in a business ecosystem

ating in the business ecosystem. For example, after entering the business ecosystem, an entrepreneur may notice that the keystone is attracting a new actor that may present a competitive threat to their business. One option is to embrace this new actor and determine how to cooperate and compete to simultaneously share value and revenues. This option is available because the entrepreneur identified the potential risk in advance and kept a watchful eye on that risk.

Table 4. Risk-identification checklist for pre-entry inspection

\begin{tabular}{|c|c|c|c|c|c|c|c|}
\hline \multirow[b]{2}{*}{ Risks } & \multicolumn{7}{|c|}{ Category of Business Ecosystem } \\
\hline & $\begin{array}{c}\text { Supply } \\
\text { Systems }\end{array}$ & $\begin{array}{l}\text { Demand } \\
\text { Forum }\end{array}$ & Platform & $\begin{array}{c}\text { Expanding } \\
\text { Communities }\end{array}$ & $\begin{array}{c}\text { Communities } \\
\text { of Destiny }\end{array}$ & Multivalent & $\begin{array}{c}\text { Risk } \\
\text { Potential }\end{array}$ \\
\hline $\begin{array}{l}\text { Complexity of relationship } \\
\text { management (actors and } \\
\text { keystones) }\end{array}$ & $\checkmark$ & $\checkmark$ & & $\checkmark$ & & $\sqrt{ }$ & Always \\
\hline $\begin{array}{l}\text { Control (centralized or } \\
\text { decentralized) }\end{array}$ & $\checkmark$ & - & $\checkmark$ & $\checkmark$ & $\checkmark$ & $\checkmark$ & Depends \\
\hline $\begin{array}{l}\text { Co-opetition (simultaneous } \\
\text { cooperation and competition) }\end{array}$ & $\checkmark$ & $\checkmark$ & $\checkmark$ & $\checkmark$ & $\checkmark$ & $\checkmark$ & Always \\
\hline $\begin{array}{l}\text { Potential loss of intellectual } \\
\text { property rights }\end{array}$ & - & - & $\checkmark$ & - & - & - & Depends \\
\hline $\begin{array}{l}\text { Centralized control of key } \\
\text { resources }\end{array}$ & - & - & $\checkmark$ & - & - & - & Depends \\
\hline $\begin{array}{l}\text { Actor/keystone reciprocal } \\
\text { interdependence }\end{array}$ & - & - & $\checkmark$ & $\checkmark$ & - & - & Depends \\
\hline $\begin{array}{l}\text { Actor } / \text { keystone pooled } \\
\text { interdependence }\end{array}$ & $\checkmark$ & $\checkmark$ & - & - & $\checkmark$ & - & Depends \\
\hline Replication of business model & - & - & - & - & - & $\checkmark$ & Depends \\
\hline
\end{tabular}




\section{Navigating Risk When Entering and Participating in a Business Ecosystem}

\section{Derek Smith}

\section{Recommendations for Entrepreneurs}

From a close reading of the published research relating to the risks associated with different categories of business ecosystems and actor participation within them, an abstraction of the problem was developed to solve the problem. The abstraction led to the environment of aviation, where risk-management techniques are commonly used to deal with ongoing risks. Then, these known risk-management techniques from aviation are brought back to the business-ecosystem context in the form of recommendations relating to the specific types of risks identified in the literature. In this section, five recommendations are presented for entrepreneurs seeking to enter and participate in a business ecosystem.

\section{Identify the category of business ecosystem before entering.}

An entrepreneur should identify the category of business ecosystem before entering into it, because the corresponding potential risks are different in each category. For example, consider an entrepreneur who is interested in joining a business ecosystem. The entrepreneur has identified a main actor with key resources that may be shared under certain rules, and the entrepreneur is interested in using these key resources to develop a product. Table 3 will assist the entrepreneur with category identification based upon the prominent attributes of different business-ecosystem categories and associated examples. In this example, the entrepreneur has identified a category of business ecosystem known as a platform.

\section{Conduct a systematic pre-entry inspection of the business ecosystem before entering.}

After identifying the category of business ecosystem, a pre-entry inspection provides an opportunity to identify and understand potential risks associated with the category. The checklist in Table 4 will assist the entrepreneur with the inspection and identification of potential risks. For platform business ecosystems, an entrepreneur should check and secure intellectual property (Koenig, 2012; tinyurl.com/cck69qa) before entering the business ecosystem to avoid loss of rights, especially if a loss of these rights impacts the company's value and ability to grow value. The entrepreneur should think about centralized or decentralized control and the amount of independence they require or will accept, and they should check the state of the business system evolution (Moore, 1993; tinyurl.com/cygzy6o) to identify evolution, or a point-intime-based risk.

\section{Practice real-time resource management after entering} the business ecosystem.

After entry into the business ecosystem, an entrepreneur should understand their company's position and role in the business ecosystem and conduct resource management in real time each day. Business ecosystems evolve and change and it is important to stay ahead of the evolution to ensure you grow value. For example, entrepreneurs should pay attention to the general risks identified in this article. They should watch keystones that may attract a competitive actor (Isckia, 2009; tinyurl.com/d659zcx), who may present a threat and either destroy or reduce the company's value. They should monitor their company's position in the value chain and look for rapid changes or convergence in the industry that may affect standards.

\section{Pay attention to horizontal relationships, because risks are different between actors.}

Horizontal relationships are key to a company's ability to grow value in a business ecosystem. An entrepreneur should check their company's dependency on component suppliers and intermediaries (Adner, 2006; tinyurl.com/cqesxlq), its position or location in the ecosystem (Adner and Kapoor, 2009; tinyurl.com/ch8bors), and the type of business relationship, co-existence, cooperation, competition and co-opetition (Bengtsson and Kock, 1999; tinyurl.com/cpyea3u). All actors in the business relationship have different risks, which can change and may inhibit the company's ability to grow value.

\section{Pay attention to coalitions, because they can add value or destroy value.}

Depending upon the situation, coalitions can be essential to a company's ability to grow value in a business ecosystem. Coalitions and horizontal relationships can be critical for standards (Calcei and M'Chirgui, 2012; tinyurl.com/bpnqnjw), and they can help when reorganizing into co-opetition relationships (Daidj and June, 2011; tinyurl.com/bqawuwz).

\section{Conclusion}

Entrepreneurs, managers, and executives should embrace business ecosystems. Entrepreneurs should consider business ecosystems for the purposes of starting up a company and growing value from day one. A systematic pre-entry inspection can identify initial business-ecosystem risks. Real-time resource management can identify participation based risks on a daily basis for corrective action. Early and ongoing identification of business-ecosystem risks are essential for to a company's success and its ability to grow value. 


\section{Navigating Risk When Entering and Participating in a Business Ecosystem}

\section{Derek Smith}

This article reviewed the published research on business ecosystems as it relates to risks, presented the content and contribution of that research in a series of tables organized by business ecosystem categories and by business ecosystem risks, abstracted a solution to the problem of risks for entry and participation, and proposed five recommendations for entrepreneurs seeking to enter and participate in business ecosystems.

Business ecosystem risks may be grouped and associated by business ecosystem category. Risks may also be grouped and associated with participating in the business ecosystem. Entrepreneurs should pay close attention to their position in the value chain and their coalitions, because the actors are very important to success in a business ecosystem.

There are three interesting opportunities for further research: i) to further define categories of business ecosystems and their associated risks; ii) to further identify and create a topology of business-ecosystem interaction and participation risks; and iii) to identify effective strategies to monitor and mitigate the risks associated with business ecosystems.

\section{About the Author}

Derek Smith is the founder and principal of Magneto Innovention Management, an intellectual property consulting firm that assists entrepreneurs and small businesses to navigate and grow their international patent portfolios. He has over 20 years of experience working as an intellectual property management consultant and patent agent for IBM Canada, Bell Canada and, most recently, Husky Injection Molding Systems where he was Director, Global Intellectual Property. Prior to entering the field of intellectual property, he was an advisory engineer at IBM Canada where he was involved in a variety of leading-edge software development projects. Derek is currently a graduate student in the Technology Innovation Management (TIM) program at Carleton University in Ottawa, Canada. He also holds a BEng degree in Systems and Computer Engineering from Carleton University and is a registered patent agent in both Canada and the United States.

Citation: Smith, D. 2013. Navigating Risk When Entering and Participating in a Business Ecosystem. Technology Innovation Management Review. May 2013: 25-33.

(cc) BY

Keywords: business ecosystem, risk, due diligence, threat management, risk identification, mitigation, entrepreneurs, startups, literature review 